\title{
AN ATTEMPT TO DETERMINE THE SCOPE OF DUTIES OF THE BUSINESS ANALYST - APPLICATION OF TEXT MINING ANALYSIS
}

\author{
Marcin WYSKWARSKI \\ Institute of Economy and Informatics, Faculty of Organization and Management of Silesian University of \\ Technology; marcin.wyskwarski@polsl.pl, ORCID: 000000032004330X
}

Purpose: An attempt to identify the scope of duties of the business analyst by analyzing job offers from websites.

Design/methodology/approach: Job offers were automatically downloaded from five websites. An analysis of text mining of fragments of offers describing the scope of duties was carried out. The analysis of text mining included initial text processing, creation of corpora of analyzed documents, creation of a document-term matrix and the use of classic methods derived from data mining.

Findings: The most frequently used words/n-grams and the correlation of selected words/ n-grams with other words/n-grams were presented in the form of drawings. Based on the frequency of words/n-grams and the correlation value, efforts were made to identify the responsibilities of the business analyst.

Research limitations/implications: Only offers written in Polish, downloaded from five websites with job offers, which had the phrase "business analyst" in their job title, were analyzed. The data was collected between 13 and 15 April 2020.

Practical implications: The method applied can be used by organizations preparing for the profession of a business analyst, to modify and better adapt curricula to the needs of the labor market.

Originality/value: Studies have shown that text mining of job offers can, to some extent, help determine the responsibilities of a business analyst.

Keywords: text mining, duties and responsibilities, business analyst.

Category of paper: research paper, case study.

\section{Introduction}

Based on the references on the subject, it can be assumed that a business analyst is a person who, regardless of the position held in the organization, runs business analysis. They are a person to ensure connectivity between the world of business and the world of IT (Information 
Technology) during activities in the implementation, development and functioning of new solutions. The main purpose of this paper was to attempt to determine the scope of responsibilities carried out by business analysts in Poland. For this purpose, an analysis of job offers downloaded from websites was carried out. The structure of work was subordinated to the adopted purpose. The second section reviews the references to define the terms "business analysis" and "business analyst". An attempt was also made to determine the role of a business analyst in the organization. The next section describes research data collection. The last section contains the results and their interpretation.

\section{Business analysis, business analyst and their role}

BABOK [Business Analysis Body of Knowledge] version 2 defines business analysis as a set of tasks and techniques used as a link between stakeholders to understand the structure, principles and activities of the organization and to present solutions that empower the organization to achieve its goals. Business analysis is understanding how the organization works to achieve its goals and what it needs to provide products and services to external stakeholders. It includes the definition of organizational goals, lines of action and tasks that the organization must undertake to achieve these goals. It also involves determining how different individuals and stakeholders interact within the organization and beyond (IIBA, 2009). BABOK version 3 defines business analysis as practical activities facilitating changes to be made in an enterprise by defining the needs and recommending solutions that are of value to stakeholders (IIBA, 2015).

J. Leyk defines business analysis as “... a set of actions targeting building relations and connections between stakeholders of a given venture and, based thereon, to define and justify the needs, detailed requirements and restrictions, and finally to propose solutions for the implementation of this venture ..." (Leyk, 2016). J. Leyk highlights the following three important aspects of business analysis (Leyk, 2016):

- it must be based on building relationships between stakeholders - the teamwork factor is emphasized,

- it is made in relation to a specific initiative or project, making it possible to identify stakeholders,

- a situation where rejecting a particular initiative or project is acceptable; such a situation may arise when the result of the analysis led to the conclusion that there was no need to make changes or no justification existed (e.g. unprofitability).

BABOK versions 2 and 3 define business analyst as any person who performs business analysis tasks, no matter their job title or organizational role (IIBA, 2009, 2015). Business analyst is seen as a liaison among the business, design and IT teams (Shah, 2017). 
Stevens defines a business analyst as an employee who is bridging the gap between employees from outside the IT industry, who have a business problem to solve, and an IT department, whose task is to find a solution (Stevens, 2012).

J. Leyk (Leyk, 2016) notes that there are at least two trends in defining the concept of business analyst. The first is related to business analysis and its definition presented in BABOK 2.0 and 3.0. The second is based on the life cycle of the project and the relationship between the commissioner of the given search and creation of the solution and the party implementing it. This approach is characteristic e.g. when creating IT solutions and the service approach represented by the ITIL ${ }^{\circledR}{ }^{1}$ IT service management standard. According to J. Leyk, the business analyst, in (Leyk, 2016):

- a narrower sense, is a person with the competence to carry out business analysis activities,

- a broader sense, a person with the competence to carry out activities involving arrangements and support to stakeholders (parties) in the development and functioning (maintenance) of a solution in all phases of its life cycle; a business analyst acts as a liaison between the business side and IT.

A business analyst must analyze and synthesize information received from a large number of people, such as customers, employees, IT specialists and managers. They are responsible for meeting the actual needs of stakeholders, not just their expressed desires. Often, a business analyst should act to facilitate communication among stakeholders. They play a key role in adapting the needs of business units to the opportunities available in information technology and can serve as a "translator" among these groups (IIBA, 2009). A business analyst plays an important role in adapting designed and delivered solutions to the needs of stakeholders (IIBA, 2015). To this end, they perform activities leading to understanding problems and goals of the company, analyzing its needs and solutions, developing strategies and facilitating cooperation among stakeholders (Vongsavanh \& Campbell, 2008).

Based on a literature review (academic and non-academic articles), Vongsavanh and Campbell stated that the role of a business analyst includes (1) collecting and analyzing business requirements, (2) acting as a liaison, bridging the gap between users and IT specialists and (3) modeling, analysis and design of current and new business processes. They formulated the following categories of business analyst roles (Vongsavanh \& Campbell, 2008):

- Mediation - results from the business analyst acting as a liaison between the users or business professionals and the IT professionals (bridging the gap between business and IT).

- Requirements Elicitation - this category includes analyzing and gathering the needs of both computer-based systems and the business.

\footnotetext{
${ }^{1}$ Information Technology Infrastructure Library.
} 
- Solution Designer - results from the designing of new business functions and/or processes.

- Business Modeling - covers the modeling and analysis of current and future business functions and processes.

- Business Problem Analysis - relates to the analysis of business problems (as opposed to gathering of requirements to create a computer-based system).

- IS (information system) Strategy Evaluation - involves the evaluation of information system strategy in relation to the business needs and goals (this differs from business problem analysis in that it generally refers to longer term strategy).

\section{Data source and analysis run}

Text mining analysis was carried out on job offers in Polish with only the phrase "business analyst" in the title. They were downloaded April 13-15, 2020, from the following five job websites:

- https://pl.indeed.com,

- https://pl.linkedin.com,

- https://www.jobs.pl,

- https://www.praca.pl,

- https://www.pracuj.pl.

Each job offer was saved on the computer hard drive. Offers were downloaded using the RStudio v.1.2.1335 development environment with the following packages installed:

- rvest v.0.3.4 (Wickham, 2019) - the package was used to analyze lists of job offers (from individual websites) in order to find their Uniform Resource Locators; each offer had its own website,

- downloader v.04 (Chang, 2016) - the package allowed downloading pages with job offers to the hard disk; each offer was saved as a separate file with the "html" extension; this procedure provided the opportunity to analyze offers even after they were removed from job offer websites.

If a job offer was repeatedly published on a given website(s), its copies were removed from the set of analyzed offers. The offer was treated as a copy when it simultaneously met the following three conditions: (1) the content of the offer was identical to the content of another offer (the content of the offer was treated as a string of characters and the comparison was made in the RStudio program using the comparison operator "=="); (2) the offer was for the same location (e.g. Poznań, Warsaw etc.); (3) the offer was posted by the same organization. 
275 offers were accepted for analysis. Fig. 1 presents the number of analyzed offers, broken down into individual Polish provinces.

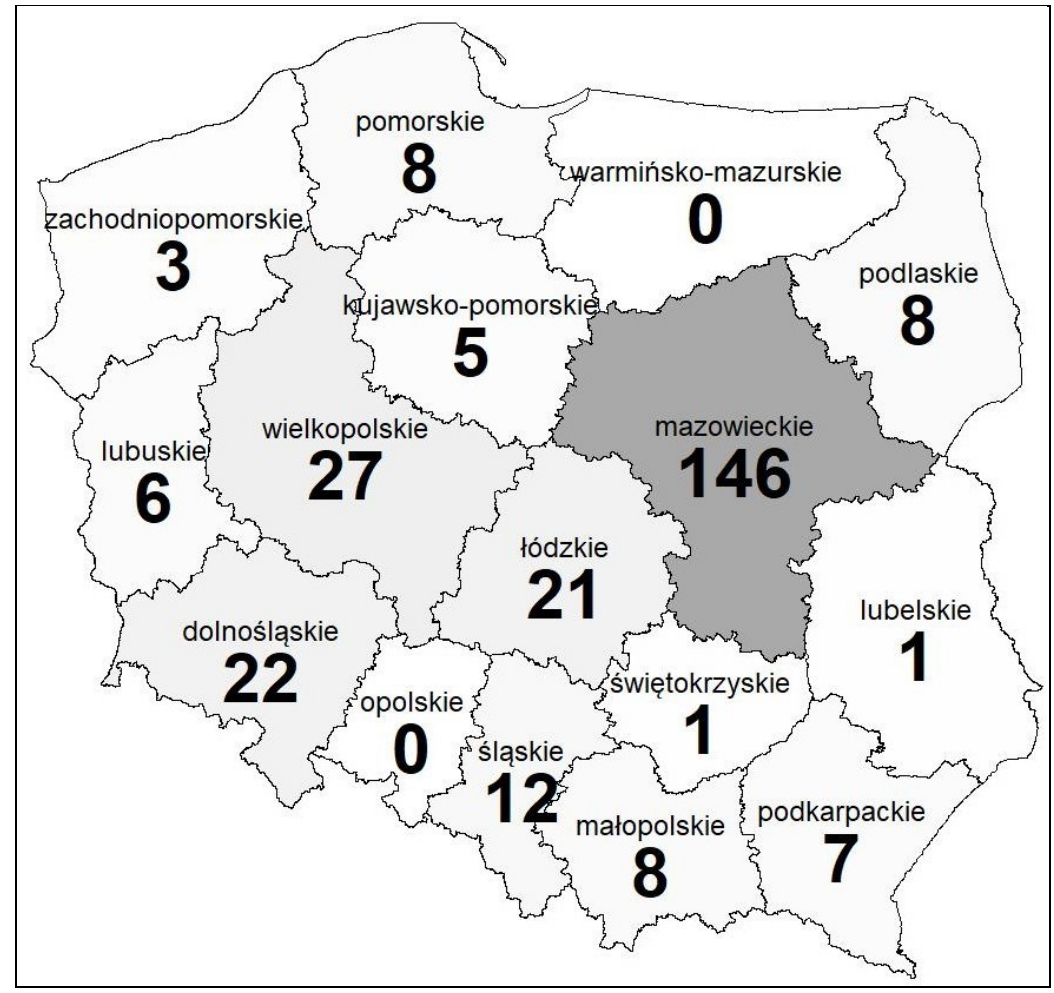

Figure 1. Number of job offers analyzed for the position of Business Analyst. Source: own work.

Data from job offers were recorded in a data frame of 5 columns by 275 rows. An individual identification number was generated for each offer, and the "rvest" package automatically retrieved information, such as job title, name and location of the organization listing the offer and content of the entire offer. Data was segregated into the following columns: id, job title, organization name, location and content of the advertisement.

\begin{tabular}{|c|c|}
\hline „zakres obowiązków” & 44 \\
\hline „zadania” & 31 \\
\hline „opis stanowiska" & 27 \\
\hline „obowiązki” & 16 \\
\hline „twoje zadania” & 15 \\
\hline „czym będziesz się zajmować” & 11 \\
\hline „kluczowe zadania” & 5 \\
\hline „będziesz odpowiedzialny za” & 4 \\
\hline „jakie zadania dla ciebie mamy” & 4 \\
\hline "na tym stanowisku będziesz odpowiedzialny za" & 4 \\
\hline „oferujemy ci miejsce, w którym będziesz" & $\overline{4}$ \\
\hline „twoje obowiązki” & 4 \\
\hline „zakres zadań” & 4 \\
\hline
\end{tabular}

Figure 2. Commonly used phrases for the title "scope of duties". Source: own work. 
Most offers did not use (or used incorrectly) HTML semantic tags that were compliant with the JobPosting ${ }^{2}$ scheme. These tags allow marking different sections in an HTML document, such as the education needed for the position ("educationRequirements" tag), the scope of responsibilities ("responsibilities" tag) or financial conditions ("baseSalary" tag).

The offers used a total of 75 different phrases to title the section describing the scope of responsibilities for the position of business analyst. The most commonly used terms are presented in Fig. 2. It lists phrases that appeared at least four times.

Due to different structures of the analyzed offers and individual section titles, a decision was made to manually create the content of two additional columns:

- scope of duties title - phrase used in the advertisement to name the scope of duties,

- scope of duties - fragment of the advertisement describing the duties.

To this end, the previously created data frame was exported to an xlsx file. Then, in the spreadsheet, using the "select, copy, paste" method, the content was added to additional columns. Next, data was imported into RStudio. Finally, the data frame evolved to accommodate 7 columns and 275 rows. Corpus 1 (275 documents) was created from fragments of the offers found in the "scope of duties" column. As the text fragments describing the scope of duties were usually shown as a bulleted list, a decision was made to create an additional body of documents, treating each bullet as a separate document. Thus, Corpus 2 with 1,563 documents was created. Corpus 2 was created automatically, taking into account the presence of EOL (End Of Line) character. 12 documents from Corpus 1 were transferred unchanged to Corpus 2 (these documents were not divided, as the content of each was written in one line/paragraph).

Using the histogram and box chart, the distribution of the number of words in the documents included in Corpora 1 and 2 was presented. As can be seen, these are relatively short pieces of text. The shortest description of duties (left side of Fig. 3) consisted of 5 words, the longest of 157 words, and on average it had 42 words. Documents from Corpus 2 are of course shorter (the shortest consists of 2 words and the longest 47 words).

In the next step, the process of initial text processing was conducted, which covered the documents from both corpora. As part of this action, all characters except letters were removed, uppercase letters were converted to lowercase letters, words deemed useless (such as stop words (conjunctions, prepositions)) were removed and words were converted to their basic form. Because the "TM" package for text mining analysis available for RStudio (Feinerer \& Hornik, 2019) does not support Polish, the transformation of words into the basic form was carried out using the morphosyntactic dictionary "polimorfologik 2.1" ("polymorphologist 2.1") This dictionary is a text file, which, after importing into RStudio, changed into a table consisting of three columns: basic form, changed form, grammar markers. The transformation of a word

\footnotetext{
${ }^{2} \mathrm{http}: / /$ schema.org/JobPosting.

${ }^{3}$ The dictionary is available at https://github.com/morfologik/polimorfologik/releases/tag/2.1.
} 
into a basic form consisted in finding it in the "modified form" column and replacing it with the "basic form" column. If the word was not found in the dictionary, it remained unchanged in the document.

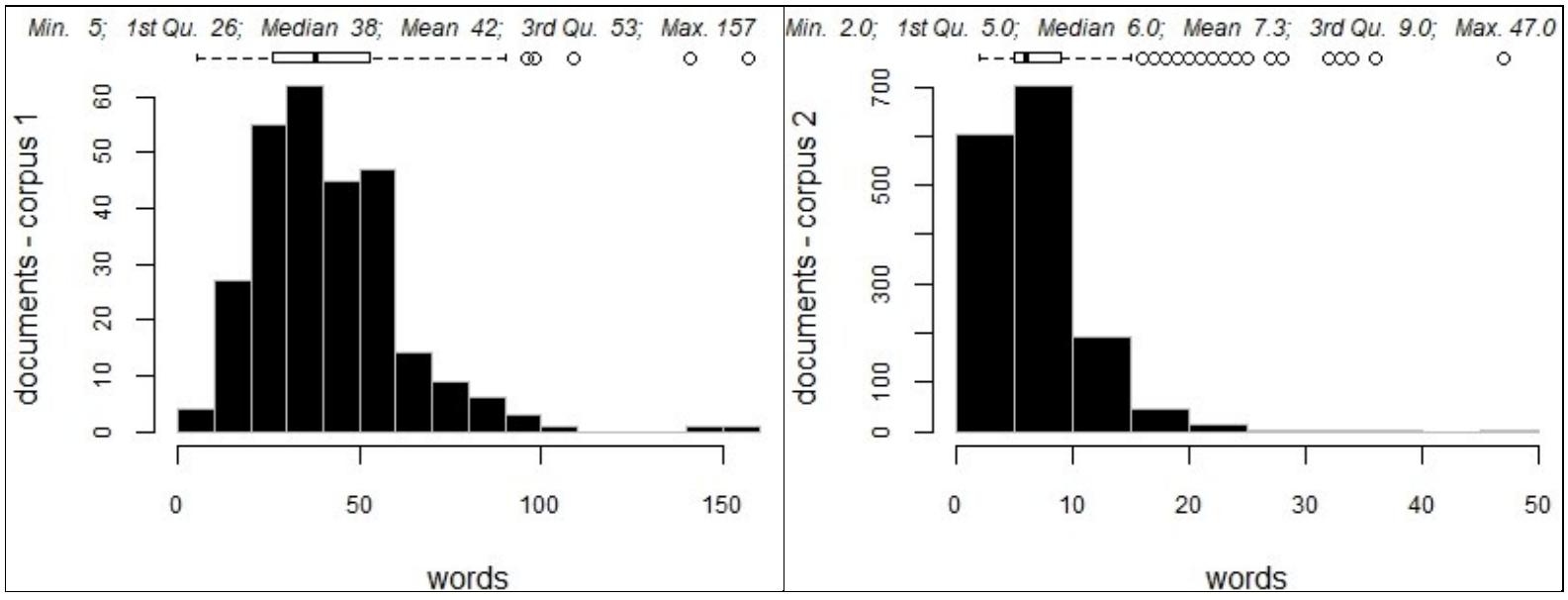

Figure 3. Number of words in Corpora 1 and 2 documents. Source: own work.

Selected n-grams were created using the regular expression mechanism. A "trial and error" method was used to create n-grams, based also on the analysis of the frequency of occurrence of specific words and their correlation with other words. The creation of n-grams was conducted by combining the words next to each other using the " " sign. For example, the side-by-side words "business" and "requirement" are combined into the n-gram "business_requirement" and the words "functional"and "requirement" into the n-gram "functional_requirement". Combining the word "requirement" with other words made it possible to determine, whether it was a business requirement or a functional requirement.

Notably, the creation of n-grams was automatic, based on the patterns set by the author. From the sample text fragment: "Analyzing the customer's business and functional requirements", only the n-gram "functional_requirement" would be created. N-gram "business_requirement" would not be created, because in this case, these two words were not next to each other. The creation of n-grams also influenced the determination of the number of occurrences of individual words in the analyzed documents. In Fig. 4. one can read that the word "business" appeared in the analyzed documents 109 times, n-gram "business_requirement" 82 times, and n-gram "business_process" 66 times. If these two n-grams had not been created, the number of occurrences of the word "business" would increase to $257(109+82+66)$. According to Fig. 4, the word "customer" was used 174 times. Actually, the number was 205. This word appeared 14 times in the "business_customer" 4 n-gram and 17 times in the "internal_customer" $n$-gram.

The next step was to create a document-term matrix for each corpus representing the term frequency $(\mathrm{TF})$.

\footnotetext{
${ }^{4}$ This n-gram is not shown in Fig. 4 due to the limit of the number of words/n-grams to 60 .

${ }^{5}$ This n-gram is not shown in Fig. 4 due to the limit of the number of words/n-grams to 60 .
} 
At the last stage, the most common words/n-grams were searched. They are shown in Fig. 4. The correlation for selected words/n-grams with other words/n-grams was also calculated. It was calculated separately for documents from Corpora 1 and 2. The correlation value is shown in Fig. 5-8. To calculate the value, the findAssocs() function was used, which is available in the "tm" package. This function is based on the standard cor() function. A correlation value of 1 means that the two words always appear together in the same number in documents, while a value of 0 means that the words never appear together. The correlation value was presented in point charts.

Based on the frequency of words/n-grams and their correlation with other words/n-grams, efforts were made to identify the scope of responsibilities of the business analyst. Individual stages (e.g. pre-cleansing of the text, creation of $n$-grams, calculation of correlations between words) were often repeated until satisfactory results were achieved.

\section{Results of the text mining analysis}

Fig. 4 presents 60 most frequently used words and n-grams in documents from Corpus 1 . (only those appearing at least 36 times are shown) ${ }^{6}$. Based on these, it is possible to try to determine what a business analyst does. The most frequently appearing words/n-grams may suggest that the business analyst mainly deals with analysis. It can be an analysis (but also collection) of data, requirements, business requirements, functional requirements, business processes (words/n-grams: "analysis", "collect", "data", "requirement", "business_requirement", “functional_requirement", "business_process"). A business analyst prepares, develops and proposes new solutions, which they then document (words/n-grams: "prepare", “develop", “propose”, “new”, “solution”, “documentation”). During the process of creating new applications, IT systems and solutions for the customer, business analyst supports and cooperates with the project team, programmers and the customer or the future user of the solution (words/n-grams: "support", “new", “application”, "IT system”, “solution", “cooperation”, “programmer”, “team”, “project”, “customer”).

\footnotetext{
${ }^{6}$ This figure is identical for Corpus 2 documents.
} 


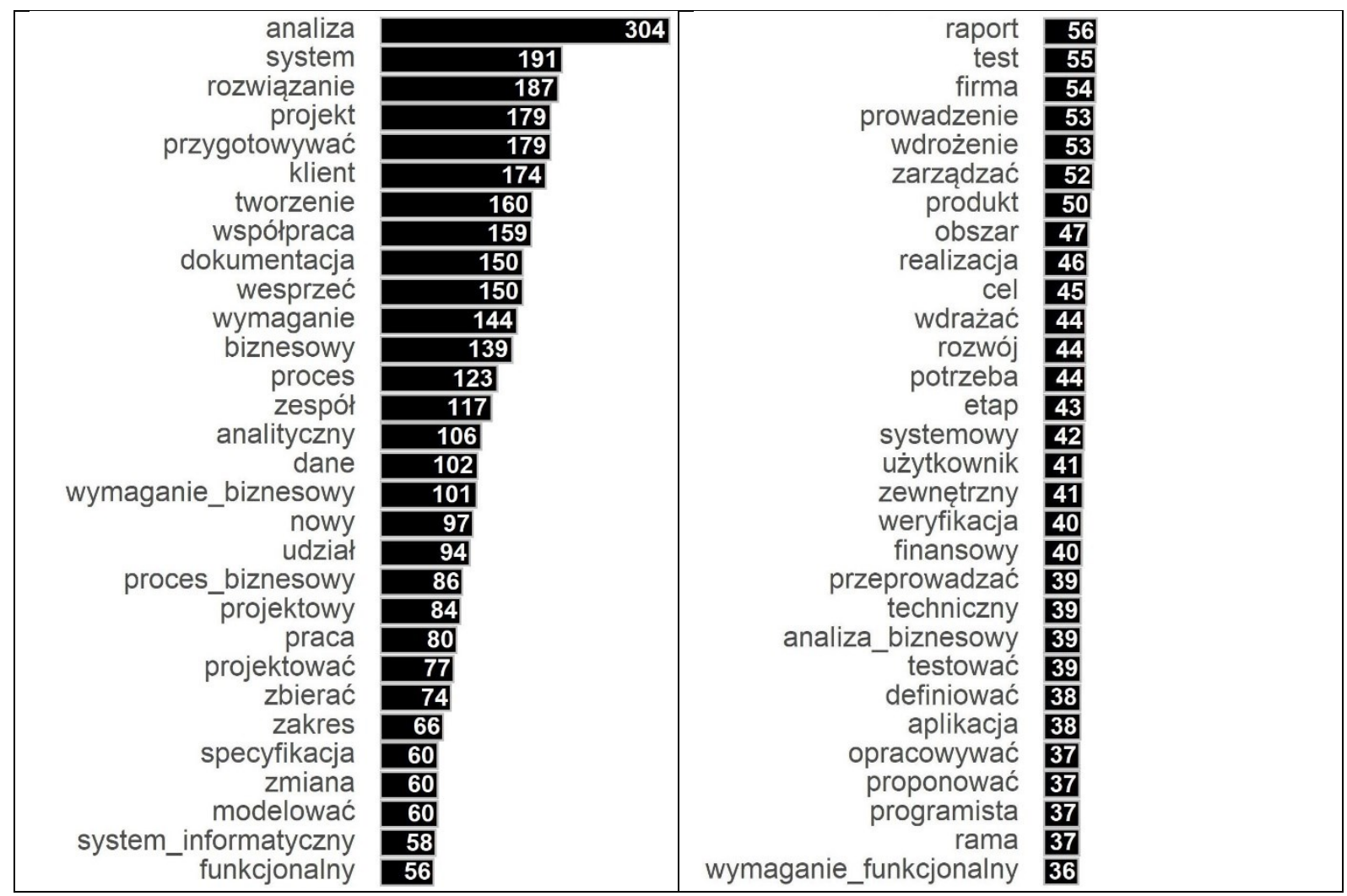

Figure 4. The most commonly used words/n-grams in documents from Corpus 1. Source: own work.

Fig. 5. shows the correlation for the most commonly used word (i.e. "Analysis") with other words/n-grams. Based on the graphs presented, a conclusion can be made that the business analyst will conduct a comprehensive analysis of various data, such as costs (words: "analysis", "comprehensive", "data", "cost") in order to include developing recommendations; assessment of correctness, feasibility and risk; draw logical conclusions (words: "develop", "recommendation", “assessment", "correctness", "feasibility", "risk", “draw", "logical”, "conclusion").

Fig. 5. also shows the correlation for the "business_process" n-gram. Based on this correlation, a conclusion can be made that the business analyst deals with mapping, modeling and optimization of business processes (words/n-grams: "map", "model", "optimize", "business_process"). During this process, business analyst creates diagrams using the appropriate notation, e.g. bpmn ${ }^{7}, \mathrm{uml}^{8}$ (words: "diagram", "notation", "uml”, "bpmn"). They allow visualization and documenting the results obtained (words: "document", "visualization").

\footnotetext{
${ }^{7}$ Business Process Model and Notation.

${ }^{8}$ Unified Modeling Language.
} 


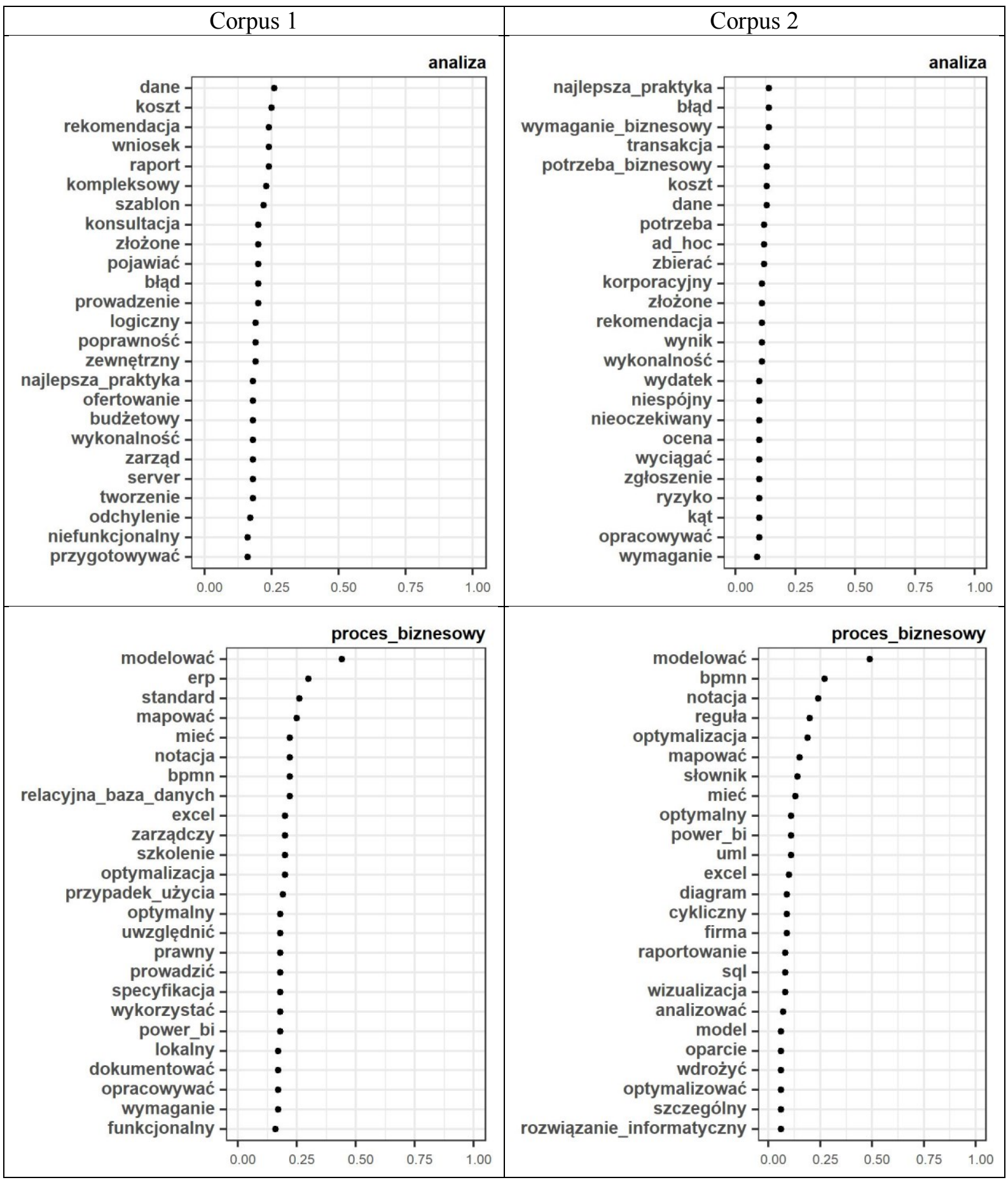

Figure 5. Correlation value - part 1. Source: own work.

Based on the correlation of the word "customer" with other words/n-grams (Fig. 6.), it can be assumed, that in their work, a business analyst will often deal with customers. They will maintain a constant relationship with customers through contact and meetings ("meeting", "contact", "relationship"). Words/n-games such as "need", "requirement", "assessment", "conducting", "credit_risk", "monitoring" indicate that the role of the analyst may also consist in analyzing customers' data to identify their needs, requirements, assessment and monitoring of their situation or credit risk. 


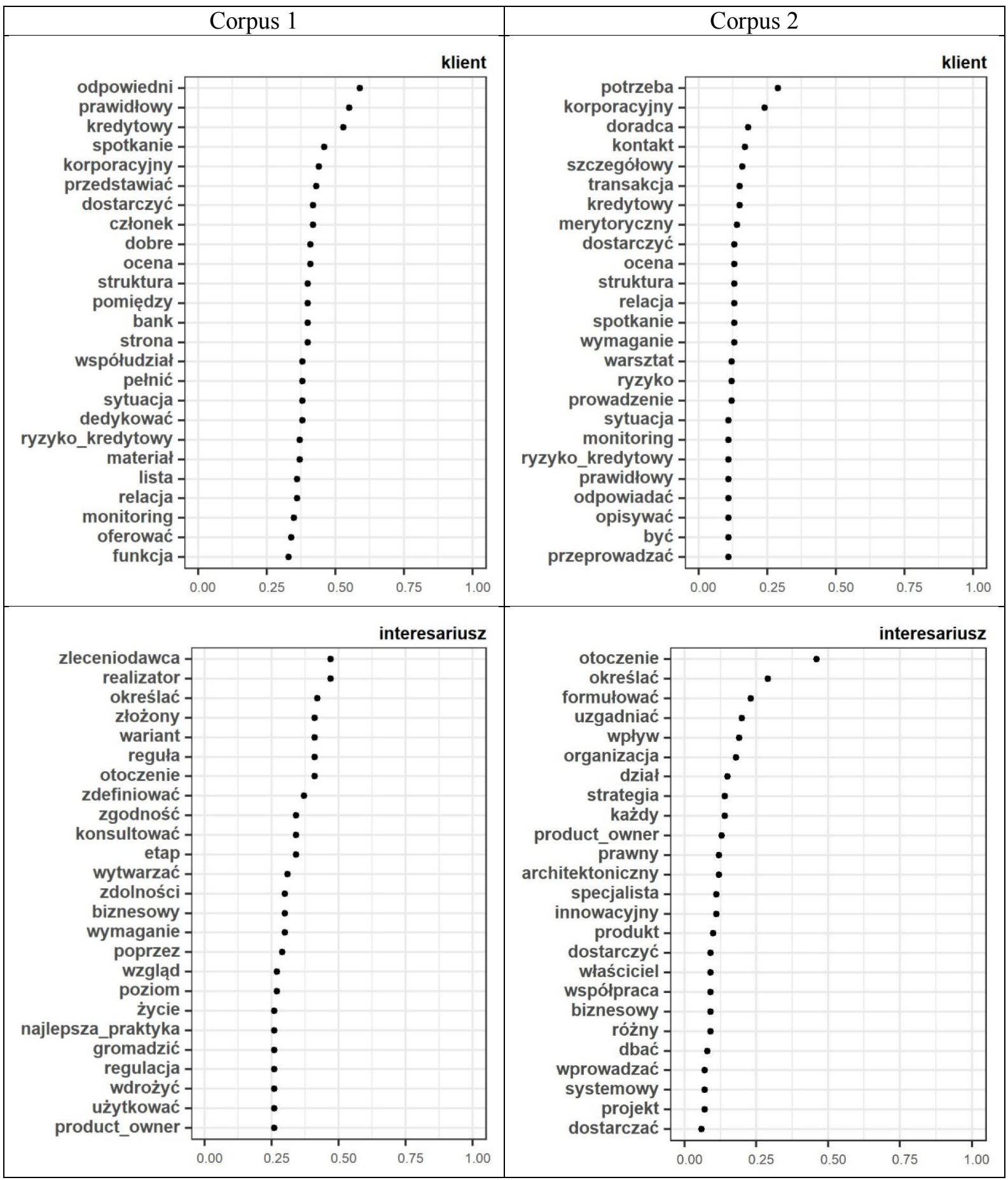

Figure 6. Correlation value - part 2. Source: own work.

Based on the correlation of the word "stakeholder" with other words (Fig. 6.), it can be assumed, that one of the tasks of a business analyst will be to specify, formulate, define the business environment and project stakeholders including their requirements and impact (words: "specify", “formulate", “define", “environment", "business", "project", "requirement", "impact"). It is also evident that the business analyst will most likely cooperate with the principal, project stakeholders, product manager and owner at every stage of the project (words/n-gram: “cooperation”, “principal”, "stakeholder”, "product_owner”, “owner”, “each”, “stage", "project"). 


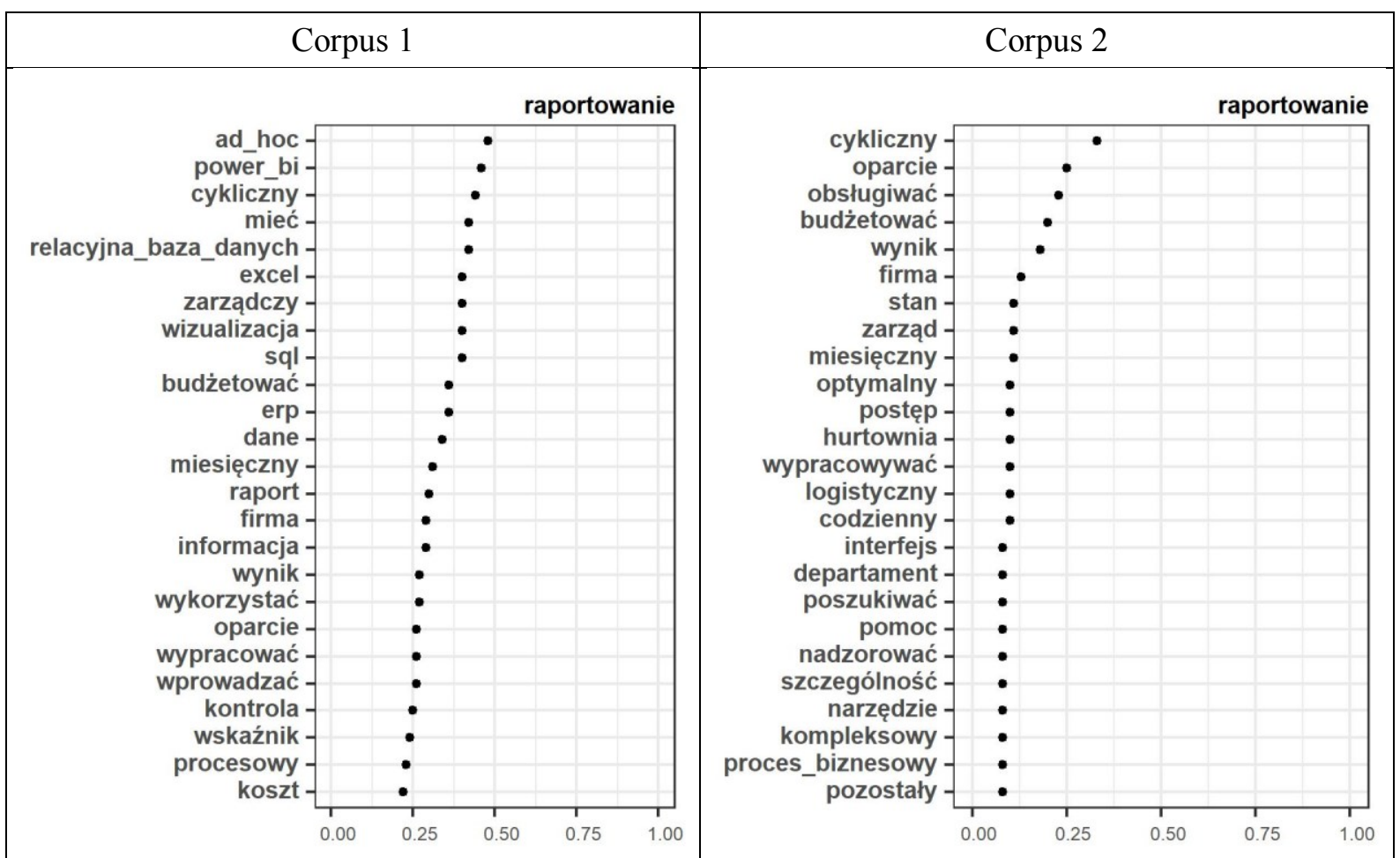

Figure 7. Correlation value - part 3. Source: own work.

The correlation shown in Fig. 7. for the word "reporting" with other words may indicate that reporting will be the sole responsibility of the business analyst. It can be periodic, monthly and/or daily reporting of, for example, results for the needs of the management board of a company or enterprise (words: "periodic", "monthly", "daily", "results", "management", "company"). Reports can also be created "ad hoc" ("ad_hoc" phrase) and the data for reports can come from relational databases, ERP systems (words/phrases: "report", "data", "relational_database", “erp"). To develop visualization and analysis, software supporting these processes will be used, i.e. "Microsoft Power BI", and "Excel" spreadsheet (words/phrases: "visualization", "use", “power_bi", “excel"). To extract data from databases, the SQL 9 language may be useful ("sql" word).

Based on the information presented in Fig. 8, it is possible to determine which industry or market the business analyst will handle. This is indicated by the words "area", "market", "medical”, "accountant", "telecommunications", “industrial”, "banking", "financial”, "mobile", "logistics", "programming", "international". Other words appearing in the said Figure allow to determine the actions performed (e.g. words: "research", "create", "report", "identify", "solve", "prepare").

\footnotetext{
${ }^{9}$ Structured Query Language.
} 


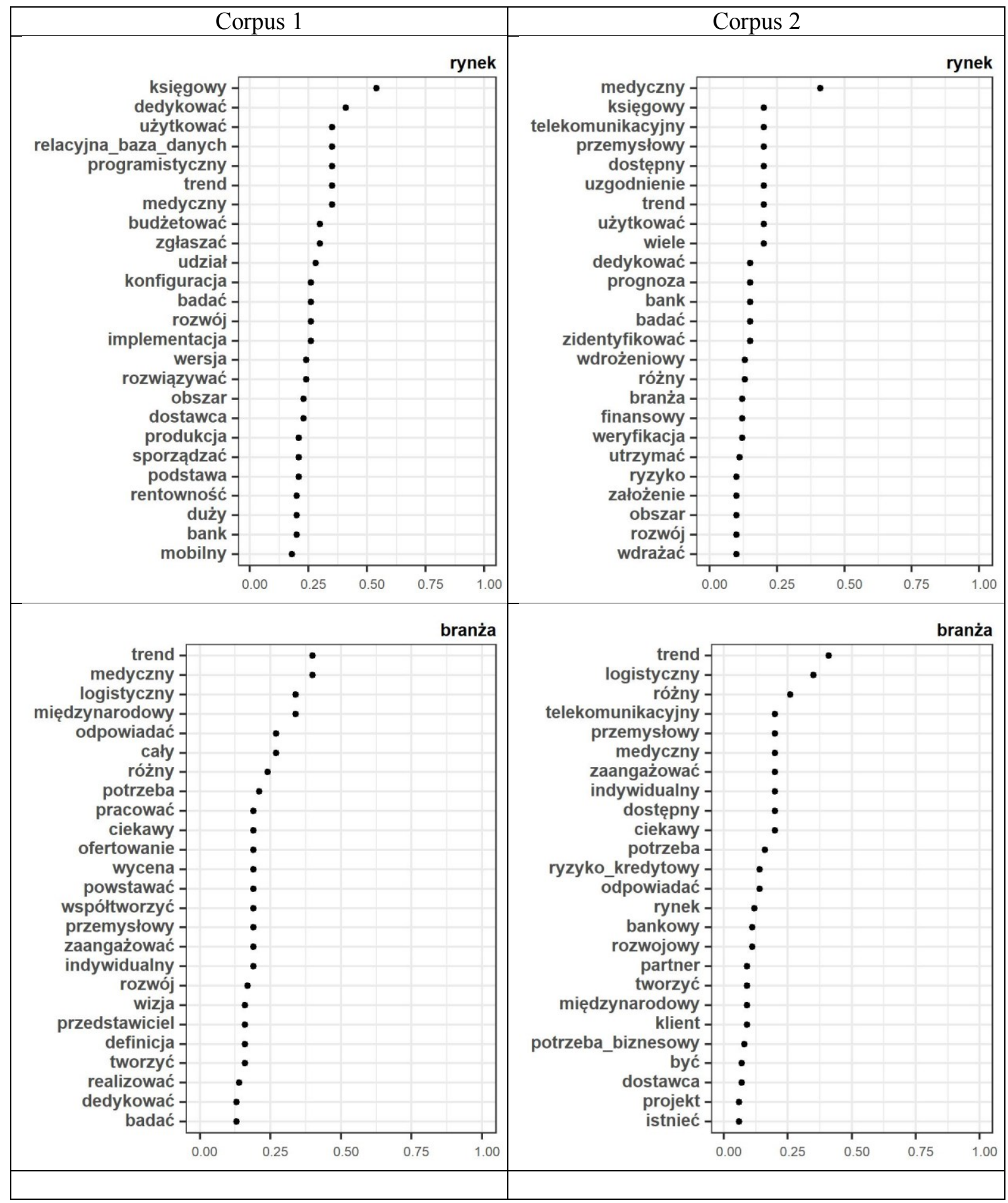

Figure 8. Correlation value - part 4. Source: own work. 


\section{Summary}

The meaning of words and sentences was not analyzed in the text mining analysis of job offers. The analysis did not take into account, whether the words in question appeared side by side in the document - except for the intentional creation of selected n-grams (e.g. "business_process"). The analysis, however, allowed to detect certain rules and regularities regarding the occurrence of specific strings in the documents analyzed (fragments of offers describing the scope of duties as a business analyst). The most commonly used words and their correlation with other words have been established. The interpretation of the results presented in point 4 is only the author's supposition, based on the frequency of words occurrence and the value of the correlation of words with other words.

\section{References}

1. Chang, W. (2016). Package 'downloader.' Retrieved from https://github.com/wch/downloader.

2. Feinerer, I., \& Hornik, K. (2019). tm: Text Mining Package. Retrieved from https://cran. r-project.org/package $=$ tm.

3. IIBA (2009). A guide to the Business Analysis Body of Knowledge (BABOK guide) (Version 2). International Institute of Business Analysis.

4. IIBA (2015). A guide to the Business Analysis Body of Knowledge (BABOK guide) (Version 3).

5. Leyk, J. (2016). Role analityka biznesowego - standard ITIL versus BABOK. Roczniki Kolegium Analiz Ekonomicznych, 40, 243-256.

6. Shah, M. (2017). Evolving role of a business analyst. International Journal of Business and Management, 1(2), 7-12. https://doi.org/10.26666/rmp.ijbm.2017.2.2.

7. Stevens, M. (2012). Bridging the Gap. Retrieved from https://www.eweek.com/enterpriseapps/bridging-the-gap.

8. Vongsavanh, A., \& Campbell, B. (2008). The roles and skill sets of systems vs business analysts. ACIS 2008 Proceedings - 19th Australasian Conference on Information Systems, 1059-1068.

9. Wickham, H. (2019). Package 'rvest.' 


\section{Appendix - translation of words used in drawings}

\section{Phrases/words from figure 2}

- będziesz odpowiedzialny za - You'll be responsible for

- czym będziesz się zajmować - What will you do

- jakie zadania dla ciebie mamy - What tasks do we have for you

- kluczowe zadania - key tasks

- na tym stanowisku będziesz odpowiedzialny za - in this position you will be responsible for

- obowiązki - responsibilities
- oferujemy ci miejsce, w którym będziesz - We offer you a place where you will be

- opis stanowiska - job description

- twoje obowiązki - Your duties

- twoje zadania - Your tasks

- zadania - tasks

- zakres obowiązków - responsibilities

- zakres zadań - task range

\section{Phrases/words from drawings from No. 3 to No. 8}

- ad_hoc-ad_hoc

- analityczny - analytical

- analiza - analysis

- analiza_biznesowy business_analysis

- analizować - analyze

- aplikacja - application

- architektoniczny architectural

- badać - research

- bank - bank

- bankowy - banking

- biznesowy - business

- błąd - error

- bpmn - BPMN

- branża - industry

- budżetować - budget

- budżetowy - financial

- być - be

- cały - entire

- cel - goal

- ciekawy - interesting

- codzienny - daily

- cykliczny - periodic

- członek - member

- dane - data

- dbać - care

- dedykować - dedicate

- definicja - definition

- definiować - define

- departament - department

- diagram - diagram

- dobre - good

- dokumentacja documentation

- dokumentować - document

- doradca - counselor

- dostarczać - deliver

- dostarczyć - deliver

- dostawca - supplier

- dostępny - available
- duży - big

- dział - department

- erp - ERP

- etap - stage

- excel - Excel

- finansowy - financial

- firma - company

- formułować - formulate

- funkcja - function

- funkcjonalny - functional

- gromadzić - collect

- hurtownia - warehouse

- implementacja implementation

- indywidualny - individual

- informacja - information

- innowacyjny - innovative

- interesariusz - stakeholder

- interfejs - interface

- istnieć - exist

- każdy - each

- kąt - angle

- klient - customer

- kompleksowy comprehensive

- konfiguracja - configuration

- konsultacja - consultation

- konsultować - consult

- kontakt - contact

- kontrola - control

- korporacyjny - corporate

- koszt - cost

- kredytowy - credit

- księgowy - accountant

- lista - list

- logiczny - logical

- logistyczny - logistics

- lokalny - local

- mapować - map

- materiał - material

- medyczny - medical
- merytoryczny - essential

- mieć - have

- miesięczny - monthly

- międzynarodowy international

- mobilny - mobile

- model - model

- modelować - model

- monitoring - monitoring

- nadzorować - oversee

- najlepsza_praktyka best_practice

- narzędzie - tool

- niefunkcjonalny nonfunctional

- nieoczekiwany unexpected

- niespójny - incoherent

- notacja - notation

- nowy - new

- obsługiwać - operate

- obszar - area

- ocena - assessment

- odchylenie - deviation

- odpowiadać - reply

- odpowiedni - suitable

- oferować - offer

- ofertowanie - making offers

- określać - specify

- oparcie - support

- opisywać - describe

- opracowywać - develop

- optymalizacja optimization

- optymalizować - optimize

- optymalny - optimum

- organizacja - organization

- otoczenie - environment

- partner - partner

- pełnić - fulfill

- podstawa - basis 
- pojawiać - appear

117

118

119

120

121

122

- pomoc-help

- poprzez - through

- postęp - progress

- potrzeba - need business need

- powstawać - arise

- poziom - level

- praca - job

- pracować - work

- prawny - legal

- proces - process business_process

- product_owner product_owner

- produkt - product

- programistyczny programming

- projekt - project

- prowadzić - lead

- przedstawiciel representative use case

- rama - frame

- raport - report
- pomiędzy - between

- poprawność - correctness

- poszukiwać - search

- potrzeba_biznesowy -

- power_bi - power_bi

- pozostały - remaining

- prawidłowy - normal

- proces_biznesowy -

- procesowy - process

- produkcja - production

- prognoza - forecast

- programista - programmer

- projektować - design

- projektowy - project

- proponować - propose

- prowadzenie - conducting

- przedstawiać - present

- przemysłowy - industrial

- przeprowadzać - conduct

- przygotowywać - prepare

- przypadek_użycia -

- raportowanie - reporting

- realizacja - implementation

- realizator - producer

- realizować - realize

- regulacja - regulation

- reguła - rule

- rekomendacja recommendation

- relacja - relationship

- relacyjna_baza_danych relational_database
- rentowność - profitability

- rozwiązanie - solution

- rozwiązanie_informatyczny - IT_solution

- rozwiązywać - solve

- rozwojowy - developmental

- rozwój - development

- różny - different

- rynek - market

- ryzyko - risk

- ryzyko_kredytowy credit risk

- server - server

- słownik - dictionary

- specjalista - expert

- specyfikacja - specification

- sporządzać - prepare

- spotkanie - meeting

- sql - sql

- stan - state

- standard - standard

- strategia - strategy

- strona - page

- struktura - structure

- system - system

- system_informatyczny - IT system

- systemowy - system

- sytuacja - situation

- szablon - template

- szczególność - peculiarity

- szczególny - special

- szczegółowy - detailed

- szkolenie - training

- techniczny - technical

- telekomunikacyjny telecommunications

- test - test

- testować - test

- transakcja - transaction

- trend - trend

- tworzenie - creation

- tworzyć - create

- udział - participation

- uml - UML

- utrzymać - maintain

- uwzględnić - consider

- uzgadniać - agree

- uzgodnienie - reconciliation

- użytkować - use

- użytkownik - user

- wariant - variant

- warsztat - workshop

- wdrażać - implement

- wdrożenie - implementation

- wdrożeniowy implementation
- wdrożyć - implement

- wersja - version

- weryfikacja - verification

- wesprzeć - support

- wiele - many

- wizja - vision

- wizualizacja - visualization

- właściciel - owner

- wniosek - conclusion

- wpływ - impact

- wprowadzać - enter

- wskaźnik - indicator

- współpraca - cooperation

- współtworzyć - contribute

- współudział - complicity

- wycena - valuation

- wyciągać - draw

- wydatek - expenditure

- wykonalność - feasibility

- wykorzystać - use

- wymaganie - requirement

- wymaganie_biznesowy business_requirement

- wymaganie_funkcjonalny functional_requirement

- wynik - results

- wypracować - elaborate

- wypracowywać - work out

- wytwarzać - produce

- wzgląd - sake

- zaangażować - get involved

- zakres - range

- założenie - assumption

- zarząd - management

- zarządczy - managerial

- zarządzać - administer

- zbierać - collect

- zdefiniować - define

- zdolności - ability

- zespół - team

- zewnętrzny - external

- zgłaszać - report

- zgłoszenie - notification

- zgodność - compatibility

- zidentyfikować - identify

- zleceniodawca - principal

- złożone - complex

- złożony - complex

- zmiana - change

- życie - life 